\title{
Effect of Different Rates and Sources of Potassium on Growth, Yield and Quality of Potato (Solanum tuberosum L.)
}

\author{
G.L. Mohan, S. Channakeshava*, N.B. Prakash, S.T. Bhairappanavar and B. Tambat \\ University of Agricultural Sciences, GKVK, Bengaluru-560065, Karnataka, India \\ *Corresponding author
}

\begin{tabular}{|l|}
\hline Key w o r d s \\
Rates and sources of \\
potassium, Growth, \\
Yield and quality. \\
\hline Article Info \\
\hline $\begin{array}{l}\text { Accepted: } \\
\text { 07 September } 2017 \\
\text { Available Online: } \\
\text { 10 November } 2017\end{array}$ \\
\hline
\end{tabular}

\section{Introduction}

Potato (Solanum tuberosum L.) is one of the most important vegetable cum food crops. It belongs to family Solanaceae and genus Solanum, is native of the Andean plateau of South America. At present, potato is grown in about 15 countries of the world on a wide range of soils and agro-climatic conditions (Khurank and Naik, 2003). Potato protein is superior to that of cereals and rich in essential amino acid 'lysine' and vitamin $\mathrm{C}$.
Hence, potato is one of the richest sources of calories needed to maintain day-to-day output of human energy Potato occupies an area of 19.2 million hectares in the world with an annual production of 373.5 million MT and an average productivity of 19.4 MT per hectare. In India, it is cultivated in an area of 2.08 million hectares with a production of 48.09 million tones and an average productivity of 23.07 tonnes per hectare 
(Anon., 2015). In Karnataka, potato occupies an area of 44,400 hectares with a production of 6.98 lakh tonnes per annum. The average yield of potato in Karnataka state is much lower $\left(14 \mathrm{t} \mathrm{ha}^{-1}\right)$ as compared to national average (23.07 $\mathrm{t} \mathrm{ha}^{-1}$ ) (Anon., 2012).The potato crop in Karnataka is mainly grown as rainfed crop in Hassan, Belagavi, Dharwad and Chikkamagaluru districts during kharif (June to September) and as an irrigated crop during Rabi (November to February) in the districts of Kolar, Chikkaballapura and Bengaluru rural. Hassan and Chikkamagaluru are the major potato producing districts under southern transitional zone of Karnataka contributing nearly 60 per cent of the total production in the state (Anon., 2006). This crop sometimes is regarded as an indicator crop for $\mathrm{K}+$ availability because of its high $\mathrm{K}$ requirement (Zameer et al., 2010).

Potassium in soil is present in three different forms that is non exchangeable $\mathrm{K}$, exchangeable $\mathrm{K}$ and $\mathrm{K}$ in soil solution. Because of low replenishment, widespread deficiency of potassium has been reported in many of the intensively cultivated soils and hence crops are responding satisfactorily to $\mathrm{K}$ application through fertilizers. Industrial growth resulted in generation of large quantity of solid and liquid wastes posing a threat to the environment. Distillery is one such industry which is generating large quantities of liquid wastes in the form of spent wash. This spent wash is generated during the fermentation of molasses to ethyl alcohol by using specific strains of yeast. It is a dark brown coloured, nontoxic liquid containing residual nutrients from sugar cane and yeast cells, does not contain heavy metals and other toxic residues. But it is highly polluting, because of its highly acidic nature and due to very high COD and BOD load in addition to high salt content. Presence of essential plant nutrients in spent wash gives us an opportunity to utilize it for crop production. Bio-K, a brown coloured powder is a value added product of distillery industry, where untreated spent wash is spray dried at high temperature. It retains most of the nutrients of spent wash and has very high potassium content (ranging from 13-15\%). This can be used as a source of $\mathrm{K}$ in agriculture. The information on use of bio-K in crops in general and potato in particular is scanty. Use of sulphate of potash (SOP) being advised for potato is costly and unaffordable for poor and marginal farmers and there is a need to find out best alternative source. Hence, the present investigation was undertaken to study "Effect of different rates and sources of potassium on growth, yield and quality of potato (Solanum tuberosum L.)".

\section{Materials and Methods}

A field experiment was conducted during Kharif season of 2016 to study the "Effect of different rates and sources of potassium on growth, yield, quality of potato (Solanum tuberosum L.)" at KVK Kandali, Hassan, University of Agricultural Sciences, Bengaluru. The experimental site is geographically situated in the Southern Transitional Zone (Zone - 7) of Karnataka and located between 12 $2^{\circ} \quad 97^{\prime}$ and $12^{\circ}$ 98' $\mathrm{N}$ Latitude and $75^{\circ} 04^{\prime}$ and $76^{\circ} 04^{\prime}$ E Longitude at an altitude of $827 \mathrm{~m}$ above Mean Sea Level. The composite soil sample from 0-15 $\mathrm{cm}$ depth was collected from the experimental site before initiation of the experiment and soil was air-dried, powdered and sieved using $2 \mathrm{~mm}$ sieve and was analyzed for physical and chemical properties (Table 1). The experiment was laid out in Randomized Completely Block Design (RCBD) with ten treatments and replicated thrice. The total number of plots was 30 (10 treatments x 3 replications). The size of each plot was $3.6 \mathrm{~m}$ x $4.2 \mathrm{~m}$. Treatments were distributed randomly in the plots within the blocks. The 
crop potato (Variety: Kufri Jyothi) was sown with spacing of $60 \mathrm{~cm} \mathrm{X} 30 \mathrm{~cm}$ and fertilizer applied as per the treatment detailed below.

\section{Treatments}

T1: Absolute control

T2: RDF (75:75:100 kg/ha NPK) $\mathrm{K}$ as $\mathrm{KCl}+$ Sulphur (Equivalent to K2SO4 in T5)

T3: RDF (75:75:150 kg/ha NPK) $\mathrm{K}$ as $\mathrm{KCl}+$ Sulphur (Equivalent to K2SO4 in T6)

T4: RDF (75:75:175 kg/ha NPK) $\mathrm{K}$ as $\mathrm{KCl}+$ Sulphur (Equivalent to K2SO4 in T7)

T5: RDF (75:75:100 kg/ha NPK) K as K2SO4

T6: RDF (75:75:150 kg/ha NPK) K as K2SO4

T7: RDF (75:75:175 kg/ha NPK) K as K2SO4

T8: RDF (75:75:100 kg/ha NPK) K as Bio K +Sulphur (Equivalent to K2SO4 in T5)

T9: RDF (75:75:150 kg/ha NPK) K as Bio K + Sulphur (Equivalent to K2SO4 in T6)

T10: RDF (75:75:175 kg/ha NPK) K as Bio K +Sulphur (Equivalent to K2SO4 in T7)

Note: RDF: Recommended dose of fertilizer for potato (75:75:100 $\left.\mathrm{kg} \mathrm{ha}^{-1} \mathrm{NPK}\right)$; FYM:

Farm Yard Manure @ $25 \mathrm{t} \mathrm{ha}^{-1}$, Sulphur from external source (T2 and T8 $=17 \mathrm{~kg}, \mathrm{~T} 3$ and $\mathrm{T} 9=25.5 \mathrm{~kg}, \mathrm{~T} 4$ and $\mathrm{T} 10=29.75 \mathrm{~kg}$ of Elemental Sulphur added to neutralize Sulphate effect)

The physical properties and chemical composition of bio-K used in field experiment, are as fallows. The moisture content, $\mathrm{pH}$ (1:10) and electrical conductivity $(1: 100)$ are $8.64 \%, 6.53$ and $0.26 \mathrm{dSm}^{-1}$, respectively. The organic carbon content of bioK is 25.5 per cent and total nitrogen, phosphorus and potassium content is 2.28, 0.12, 13.5 per cent, respectively. Calcium, magnesium and sulphur content is $1.52,2.40$, 1.46 .

The observations on plant height, number of branches per plant leaf area, total dry matter production, number of tubers per plant, tuber weight and tuber yield recorded at 90 days after planting. Haulm and tuber samples collected at 90DAP and were analysed for total $\mathrm{N}, \mathrm{P}, \mathrm{K}, \mathrm{Ca}, \mathrm{Mg}, \mathrm{S}, \mathrm{Zn}, \mathrm{Cu}, \mathrm{Mn}, \mathrm{Fe}$ and $\mathrm{B}$ content using standard methods. Postharvest soil samples collected were analysed for $\mathrm{pH}$, electrical conductivity (EC), organic carbon, available nutrient status $(\mathrm{N}, \mathrm{P}, \mathrm{K}, \mathrm{Ca}$, $\mathrm{Mg}, \mathrm{S}, \mathrm{Fe}, \mathrm{Mn}, \mathrm{Cu}, \mathrm{Zn}$ and $\mathrm{B}$ ) using standard methods (Table 2). The experimental data obtained were subjected to statistical analysis adopting Fisher's method of analysis of variance as out lined by Gomez and Gomez (1984). The level of significance used in ' $F$ ' test was given at 5 per cent. Critical difference (CD) values were given in the table at 5 per cent level of significance, wherever the ' $F$ ' test was significant at 5 per cent level.

\section{Results and Discussion}

Results revealed that application of 75:75:175 $\mathrm{kg}$ per hectare of NPK where $\mathrm{K}$ applied as Bio-K recorded highest plant height, number of branches and total dry matter production per plant and however was on par with application of 75:75:175 kg/ha of NPK where $\mathrm{K}$ applied as Sulphate of Potash (Table 2). Significantly lower plant height, number of branches leaf area, leaf number and total dry matter production per plant recorded in absolute control. Among the different sources of $\mathrm{K}$ application of $175 \mathrm{~kg} / \mathrm{ha}$ of $\mathrm{K}$ as $\mathrm{KCl}$ recorded significantly lower growth parameter (Plant height number of branches and total dry matter production per plant). 
Application of 75:75: $175 \mathrm{~kg} / \mathrm{ha}$ NPK where $\mathrm{K}$ applied as Bio- $\mathrm{K}$ recorded significantly higher number of tubers per plant (4.8) and tuber weight per plant $(560.67 \mathrm{~g})$ and however was on par with application of 75:75: $175 \mathrm{~kg} / \mathrm{ha}$ NPK where $\mathrm{K}$ applied as SOP (4.6 and 545.07g). Among the $\mathrm{K}$ sources, performance of Bio-K found to be superior to $\mathrm{SOP}$ and $\mathrm{KCl}$ with respect to yield parameters of potato. Significantly lower number of tubers and tuber weight recorded in absolute control (2.4 and 198). The increase in growth parameters may be due to increased cell division and cell elongation. These results are in conformity with the findings of Krishnappa and Shivasankar (1981), As regard to tuber yield per hectare application $75: 75: 175 \mathrm{~kg}$ per hectare of NPK with $\mathrm{K}$ as Bio-K (Tabl-3) recorded highest tuber yield per hectare $(31.15 \mathrm{t} / \mathrm{ha}$ ) and was on par with application 75:75:175 kg per hectare of NPK where $\mathrm{K}$ applied as SOP (30.28 t/ha).

However, tuber yield per hectare did not differ significantly due to application of SOP and Bio-K at all the rates. Significantly lower tuber yield was recorded in absolute control $(11.0 \mathrm{t} / \mathrm{ha})$. Increase in yield and yield attributes due to immediate availability of $\mathrm{K}$ from Bio-K source (Ahmed et al., 2009).

\section{Effect of different rate and sources of $K$ on quality of potato tuber}

The quality parameter like starch and protein content differed significantly due to application of different rate and sources of $\mathrm{K}$ (Table 3). Significantly higher starch and protein content in tuber was recorded with application 75:75:175 kg per hectare of NPK where $\mathrm{K}$ applied as Bio-K and was on par with application of $100 \mathrm{~kg}, 150 \mathrm{~kg}$ and $175 \mathrm{~kg}$ of $\mathrm{K}$ as SOP and bio-K at 100 and $150 \mathrm{~kg}$ along with recommended $\mathrm{N}$ and $\mathrm{P}$ (75:75 $\mathrm{kg} / \mathrm{ha}$ ). Significantly lower protein and starch content was recorded in absolute control. The increase in quality of potato due to higher availability and uptake of $\mathrm{K}$ from the Bio-K source. These results were in agreement with findings of Sharma et al., (1976).

Table.1 Initial physico-chemical properties of soil at experimental site

\begin{tabular}{|l|l|l|}
\hline SLNO & Parameters & Value \\
\hline 1 & Sand $(\%)$ & 73.10 \\
\hline 2 & Silt $(\%)$ & 12.15 \\
\hline 3 & Clay $(\%)$ & 14.75 \\
\hline \multicolumn{2}{|c|}{ Chemical properties } \\
\hline 4 & $\mathrm{pH} 1: 2.5)$ & 7.25 \\
\hline 5 & EC $(\mathrm{dS} / \mathrm{m})$ & 0.41 \\
\hline 6 & Organic Carbon (\%) & 6.70 \\
\hline 7 & Available $\mathrm{N}\left(\mathrm{kg} \mathrm{ha}^{-1}\right)$ & 297.5 \\
\hline 8 & Available $\mathrm{P}_{2} \mathrm{O}_{5}\left(\mathrm{~kg} \mathrm{ha}^{-1}\right)$ & 45.80 \\
\hline 9 & Available $\mathrm{K}_{2} \mathrm{O}_{\left(\mathrm{kg} \mathrm{ha}^{-1}\right)} \mathrm{Micronutrients}^{-1}$ & 168.60 \\
\hline \multicolumn{2}{|c|}{} \\
\hline 10 & DTPA Fe $\left(\mathrm{mg} \mathrm{kg}^{-1}\right)$ & 14.60 \\
\hline 11 & DTPA Mn $\left(\mathrm{mg} \mathrm{kg}^{-1}\right)$ & 17.60 \\
\hline 12 & DTPA Zn $\left(\mathrm{mg} \mathrm{kg}^{-1}\right)$ & 1.36 \\
\hline 13 & DTPA Cu $\left(\mathrm{mg} \mathrm{kg}^{-1}\right)$ & 1.24 \\
\hline 14 & Hot water soluble Boron $\left(\mathrm{mg} \mathrm{kg}^{-1}\right)$ & 0.23 \\
\hline
\end{tabular}


Table.2 Methodology for soil and plant analysis

\begin{tabular}{|c|c|c|c|}
\hline SLNO & Parameter & Procedure & Method and Reference \\
\hline \multicolumn{4}{|c|}{ Soil analysis } \\
\hline 1 & Particle size analysis & $\begin{array}{l}\text { Soil was treated with } \mathrm{H}_{2} \mathrm{O}_{2} \text {, dispersed with sodium } \\
\text { hexametaphosphate, sand with decantation procedure, silt and clay in } \\
\text { the suspension was measured after pipetting with Robinson pipette. }\end{array}$ & International pipette method, Jackson (1973) \\
\hline 2 & Soil reaction & $\begin{array}{l}\text { Soil:water suspension }(1: 2.5) \text { was measured for } \mathrm{pH} \text { using } \\
\text { potentiometer after standardizing with appropriate buffers }\end{array}$ & Potentiometry, Jackson (1973) \\
\hline 3 & Electrical conductivity & $\begin{array}{l}\text { Soil:water extract }(1: 2.5) \text { was measured for EC using conductivity } \\
\text { bridge }\end{array}$ & Conductometry Jackson (1973) \\
\hline 4 & Organic carbon & $\begin{array}{l}\text { Soil was digested with } \mathrm{K}_{2} \mathrm{Cr}_{2} \mathrm{O}_{7} \text { and conc. } \mathrm{H} 2 \mathrm{SO} 4 \text {. The unutilized } \\
\mathrm{K} 2 \mathrm{Cr} 2 \mathrm{O} 7 \text { was back titrated against ferrous ammonium sulphate using } \\
\text { diphenyl amine indicator. }\end{array}$ & Wet oxidation, Walkely and Black (1934) \\
\hline 5 & Available Nitrogen & $\begin{array}{l}\text { Soil was oxidised and distilled with alkaline potassium permanganate } \\
\text { and then titrated against standard acid using mixed indicator. }\end{array}$ & Subbaiah and Asija (1956) \\
\hline 6 & Available phosphorus & $\begin{array}{l}\text { Soil was extracted with Brays-1 and estimated by chloromolybdate } \\
\text { acid method using spectrophotometer and intensity of blue colour } \\
\text { measured at } 660 \mathrm{~nm} \text {. }\end{array}$ & Brays -I method, Brays and Kurtz (1945) \\
\hline 7 & Available potassium & $\begin{array}{l}\text { Extracted the soil with } 1 \mathrm{~N}(\mathrm{pH} 7) \text { ammonium acetate and estimated } \\
\text { with flame photometer. }\end{array}$ & Flame photometry, Jackson (1973) \\
\hline 8 & $\begin{array}{l}\text { DTPA extractable } \mathrm{Fe}, \mathrm{Mn}, \mathrm{Zn} \text {, } \\
\mathrm{Cu}\end{array}$ & $\begin{array}{l}\text { Extracted the soil with DTPA and estimated with atomic absorption } \\
\text { spectrophotometer }\end{array}$ & Lindsay and Norwell (1978) \\
\hline 9 & Available boron & Azomethane-H reagent method & Gupta (1979) \\
\hline 10 & Total plant nitrogen & $\begin{array}{l}\text { Plant sample digested in concentrated sulphuric acid and digestion } \\
\text { mixture }\left(\mathrm{K}_{2} \mathrm{SO}_{4}: \mathrm{CuSO}_{4}: \text { Selenium in } 100: 20: 1 \text { proportion). The }\right. \\
\text { digested sample was distilled by micro Kjeldhal distillation method. } \\
\text { The liberated ammonia was trapped in boric acid and estimated by } \\
\text { titration against standard sulphuric acid. }\end{array}$ & Piper (1966) \\
\hline 11 & Total plant Phosphorus & $\begin{array}{l}\text { Phosphorus in di acid digested plant sample estimated by forming } \\
\text { yellow colour phosphovanadomolybdate complex using } \\
\text { spectrophotometer at } 430 \mathrm{~nm} \text {. }\end{array}$ & $\begin{array}{l}\text { Phosphovanado molybdate complex method, } \\
\text { Baruah and Barthakur (1997) }\end{array}$ \\
\hline 12 & Total plant Potassium & $\begin{array}{l}\text { Potassium in diacid digested plant sample was estimated with flame } \\
\text { photometer }\end{array}$ & Flame photometry, Jackson (1973) \\
\hline 13 & Total plant Micronutrients & $\begin{array}{l}\text { Micronutrients in diacid digested plant samples were determined } \\
\text { using Atomic Absorption Spectrophotometer }\end{array}$ & Lindsay and Norvell (1978) \\
\hline 14 & Boron & $\begin{array}{l}\text { The diacid digested plant samples were treated with Azomethane-H } \\
\text { reagent and colour was measured at } 420 \mathrm{~nm} \text { using Spectrophotometer }\end{array}$ & Azomethane-H method Jones and Case (1990) \\
\hline
\end{tabular}


Table.3 Effect of different rates and sources of potassium on growth parameters of potato

\begin{tabular}{|c|c|c|c|}
\hline \multirow[t]{2}{*}{ Treatments } & \multicolumn{3}{|c|}{ Growth parameters at harvest (90DAS) } \\
\hline & $\begin{array}{l}\text { Plant height } \\
\text { (cm) }\end{array}$ & No. of branches & $\begin{array}{l}\text { Total Dry matter production } \\
\text { (Kg/ha) (Haulm + tuber) }\end{array}$ \\
\hline T1: Absolute control & 54.51 & 1.99 & 2063.02 \\
\hline T2: RDF (75:75:100 kg/ha NPK) $\mathrm{K}$ as $\mathrm{KCl}+$ Sulphur (Equivalent to $\mathrm{K}_{2} \mathrm{SO}_{4}$ in T5) & 58.72 & 2.13 & 3789.76 \\
\hline T3: RDF (75:75:150 kg/ha NPK) $\mathrm{K}$ as $\mathrm{KCl}+$ Sulphur (Equivalent to $\mathrm{K}_{2} \mathrm{SO}_{4}$ in T6) & 64.5 & 2.23 & 4072.04 \\
\hline T4: RDF (75:75:175 kg/ha NPK) $\mathrm{K}$ as $\mathrm{KCl}+$ Sulphur (Equivalent to $\mathrm{K}_{2} \mathrm{SO}_{4}$ in T7) & 64.84 & 2.26 & 4711.24 \\
\hline T5: RDF (75:75:100 kg/ha NPK) $\mathrm{K}$ as $\mathrm{K}_{2} \mathrm{SO}_{4}$ & 61.74 & 2.27 & 5566.38 \\
\hline T6: RDF (75:75:150 kg/ha NPK) $\mathrm{K}$ as $\mathrm{K}_{2} \mathrm{SO}_{4}$ & 63.0 & 2.33 & 5660.00 \\
\hline T7: RDF (75:75:175 kg/ha NPK) $\mathrm{K}$ as $\mathrm{K}_{2} \mathrm{SO}_{4}$ & 69.56 & 2.43 & 6061.26 \\
\hline T8: RDF (75:75:100 kg/ha NPK) K as Bio K +Sulphur (Equivalent to $\mathrm{K}_{2} \mathrm{SO}_{4}$ in T5) & 65.11 & 2.45 & 5595.93 \\
\hline T9: RDF (75:75:150 kg/ha NPK) K as Bio $\mathrm{K}+$ Sulphur (Equivalent to $\mathrm{K}_{2} \mathrm{SO}_{4}$ in T6) & 67.79 & 2.50 & 5651.90 \\
\hline T10: RDF (75:75:175 kg/ha NPK) $\mathrm{K}$ as Bio $\mathrm{K}+$ Sulphur (Equivalent to $\mathrm{K}_{2} \mathrm{SO}_{4}$ in T7) & 72.60 & 2.83 & 6366.04 \\
\hline S.Em. \pm & 1.70 & 0.14 & 248.93 \\
\hline CD@ $5 \%$ & 5.06 & 0.41 & 739.60 \\
\hline
\end{tabular}

Table.4 Effect of different rates and sources of potassium on yield and quality parameters of potato

\begin{tabular}{|c|c|c|c|}
\hline Treatments & Tuber yield (t/ha) & Starch (\%) & Protein (\%) \\
\hline T1: Absolute control & 11.0 & 58.17 & 6.24 \\
\hline T2: RDF (75:75:100 kg/ha NPK) $\mathrm{K}$ as $\mathrm{KCl}+$ Sulphur (Equivalent to $\mathrm{K}_{2} \mathrm{SO}_{4}$ in T5) & 19.37 & 65.60 & 6.91 \\
\hline T3: RDF (75:75:150 kg/ha NPK) $\mathrm{K}$ as $\mathrm{KCl}+$ Sulphur (Equivalent to $\mathrm{K}_{2} \mathrm{SO}_{4}$ in T6) & 19.37 & 68.34 & 6.77 \\
\hline T4: RDF (75:75:175 kg/ha NPK) $\mathrm{K}$ as $\mathrm{KCl}+$ Sulphur (Equivalent to $\mathrm{K}_{2} \mathrm{SO}_{4}$ in T7) & 23.01 & 68.46 & 6.88 \\
\hline T5: $\mathrm{RDF}(75: 75: 100 \mathrm{~kg} / \mathrm{ha} \mathrm{NPK}) \mathrm{K}$ as $\mathrm{K}_{2} \mathrm{SO}_{4}$ & 28.05 & 70.53 & 7.58 \\
\hline T6: RDF (75:75:150 kg/ha NPK) $\mathrm{K}$ as $\mathrm{K}_{2} \mathrm{SO}_{4}$ & 28.50 & 70.68 & 7.70 \\
\hline T7: RDF (75:75:175 kg/ha NPK) K as $\mathrm{K}_{2} \mathrm{SO}_{4}$ & 30.28 & 74.66 & 8.34 \\
\hline T8: RDF (75:75:100 kg/ha NPK) K as Bio $\mathrm{K}+$ Sulphur (Equivalent to $\mathrm{K}_{2} \mathrm{SO}_{4}$ in T5) & 28.09 & 71.90 & 8.02 \\
\hline T9: RDF (75:75:150 kg/ha NPK) $\mathrm{K}$ as Bio $\mathrm{K}+$ Sulphur (Equivalent to $\mathrm{K}_{2} \mathrm{SO}_{4}$ in T6) & 28.62 & 73.07 & 8.17 \\
\hline T10: RDF (75:75:175 kg/ha NPK) $\mathrm{K}$ as Bio $\mathrm{K}+$ Sulphur (Equivalent to $\mathrm{K}_{2} \mathrm{SO}_{4}$ in T7) & 31.15 & 79.27 & 8.50 \\
\hline S.Em. \pm & 1.11 & 3.25 & 0.46 \\
\hline CD@ $9 \%$ & 3.29 & 9.65 & 1.38 \\
\hline
\end{tabular}


Table.5 Effect of different rates and sources of potassium on total N, P and K content (\%) in haulm and tuber

\begin{tabular}{|c|c|c|c|c|c|c|}
\hline \multirow[t]{2}{*}{ Treatments } & \multicolumn{2}{|c|}{$\mathbf{N}$} & \multicolumn{2}{|c|}{$\mathbf{P}$} & \multicolumn{2}{|c|}{$\mathbf{K}$} \\
\hline & Haulm & Tuber & Haulm & Tuber & Haulm & Tuber \\
\hline T1: Absolute control & 1.12 & 1.00 & 0.20 & 0.26 & 1.28 & 1.45 \\
\hline T2: RDF (75:75:100 kg/ha NPK) K as $\mathrm{KCl}+$ Sulphur (Equivalent to $\mathrm{K}_{2} \mathrm{SO}_{4}$ in T5) & 1.14 & 1.22 & 0.21 & 0.32 & 1.73 & 1.59 \\
\hline T3: RDF (75:75:150 kg/ha NPK) $\mathrm{K}$ as $\mathrm{KCl}+$ Sulphur (Equivalent to $\mathrm{K}_{2} \mathrm{SO}_{4}$ in T6) & 1.16 & 1.23 & 0.21 & 0.36 & 1.89 & 1.63 \\
\hline T4: RDF (75:75:175 kg/ha NPK) K as KCl + Sulphur (Equivalent to $\mathrm{K}_{2} \mathrm{SO}_{4}$ in T7) & 1.17 & 1.24 & 0.23 & 0.29 & 2.10 & 1.63 \\
\hline T5: RDF (75:75:100 kg/ha NPK) K as $\mathrm{K}_{2} \mathrm{SO}_{4}$ & 1.26 & 1.25 & 0.24 & 0.36 & 2.43 & 1.64 \\
\hline T6: $\mathrm{RDF}(75: 75: 150 \mathrm{~kg} / \mathrm{ha} \mathrm{NPK}) \mathrm{K}$ as $\mathrm{K}_{2} \mathrm{SO}_{4}$ & 1.28 & 1.26 & 0.24 & 0.35 & 2.50 & 1.65 \\
\hline T7: RDF (75:75:175 kg/ha NPK) $\mathrm{K}$ as $\mathrm{K}_{2} \mathrm{SO}_{4}$ & 1.31 & 1.31 & 0.26 & 0.40 & 2.72 & 1.71 \\
\hline T8: RDF (75:75:100 kg/ha NPK) $\mathrm{K}$ as Bio $\mathrm{K}+$ Sulphur (Equivalent to $\mathrm{K}_{2} \mathrm{SO}_{4}$ in T5) & 1.30 & 1.26 & 0.24 & 0.39 & 2.67 & 1.67 \\
\hline T9: RDF (75:75:150 kg/ha NPK) K as Bio K +Sulphur (Equivalent to $\mathrm{K}_{2} \mathrm{SO}_{4}$ in T6) & 1.33 & 1.32 & 0.26 & 0.41 & 2.73 & 1.74 \\
\hline T10: RDF (75:75:175 kg/ha NPK) K as Bio $\mathrm{K}+$ Sulphur (Equivalent to $\mathrm{K}_{2} \mathrm{SO}_{4}$ in T7) & 1.35 & 1.34 & 0.27 & 0.43 & 2.87 & 1.75 \\
\hline S.Em. \pm & $\mathbf{0 . 0 1}$ & $\mathbf{0 . 0 2}$ & $\mathbf{0 . 0 1}$ & $\mathbf{0 . 0 1}$ & $\mathbf{0 . 0 5}$ & $\mathbf{0 . 0 2}$ \\
\hline CD@ $5 \%$ & 0.04 & 0.06 & $\mathbf{0 . 0 2}$ & $\mathbf{0 . 0 3}$ & 0.15 & 0.05 \\
\hline
\end{tabular}

Table.6 Effect of different rates and sources of potassium on total $\mathrm{Fe}, \mathrm{Mn}, \mathrm{Zn}, \mathrm{Cu}$ and $\mathrm{B}$ conten $\mathrm{t}(\%)$ in haulm and tuber

\begin{tabular}{|c|c|c|c|c|c|c|c|c|c|c|}
\hline \multirow[t]{2}{*}{ Treatments } & \multicolumn{2}{|c|}{$\mathbf{F e}$} & \multicolumn{2}{|c|}{ Mn } & \multicolumn{2}{|c|}{ Zn } & \multicolumn{2}{|c|}{$\mathbf{C u}$} & \multicolumn{2}{|c|}{ B } \\
\hline & Haulm & Tuber & Haulm & Tuber & Haulm & Tuber & Haulm & Tuber & Haulm & Tuber \\
\hline $\mathrm{T} 1$ & 203.67 & 127.20 & 96.56 & 28.41 & 21.96 & 8.74 & 29.60 & 13.92 & 7.13 & 9.0 \\
\hline $\mathrm{T} 2$ & 210.63 & 127.45 & 99.05 & 32.34 & 25.63 & 9.52 & 28.53 & 16.48 & 7.35 & 10.42 \\
\hline T3 & 215.83 & 121.07 & 104.57 & 38.94 & 29.01 & 9.73 & 28.58 & 16.83 & 7.79 & 11.90 \\
\hline $\mathrm{T} 4$ & 220.15 & 130.67 & 113.03 & 42.72 & 29.57 & 8.82 & 29.61 & 17.68 & 7.58 & 12.89 \\
\hline $\mathrm{T5}$ & 229.15 & 134.49 & 126.27 & 46.95 & 31.55 & 10.65 & 30.23 & 19.22 & 8.40 & 13.27 \\
\hline T6 & 245.75 & 134.05 & 135.27 & 49.62 & 37.26 & 9.54 & 29.44 & 19.72 & 7.86 & 13.48 \\
\hline $\mathrm{T} 7$ & 255.51 & 136.64 & 140.57 & 48.56 & 38.42 & 9.64 & 30.02 & 21.73 & 8.40 & 13.62 \\
\hline $\mathrm{T} 8$ & 272.98 & 138.06 & 145.52 & 48.28 & 40.80 & 10.33 & 31.70 & 24.65 & 9.30 & 13.58 \\
\hline T9 & 274.67 & 140.37 & 150.15 & 51.37 & 43.93 & 11.85 & 31.99 & 26.02 & 9.55 & 15.55 \\
\hline $\mathrm{T} 10$ & 277.63 & 147.06 & 152.41 & 53.60 & 44.54 & 12.37 & 32.85 & 26.65 & 9.82 & 16.53 \\
\hline S.Em. \pm & 1.89 & 2.47 & 1.33 & 0.76 & 0.67 & 0.23 & 0.80 & 0.50 & 0.09 & 0.36 \\
\hline CD @ 5\% & 5.63 & 7.34 & 3.94 & 2.25 & 1.99 & 0.68 & 2.39 & 1.48 & 0.27 & 1.07 \\
\hline
\end{tabular}


Table.7 Economics of potato as influenced by application of different rates and sources of potassium in potato

\begin{tabular}{|c|c|c|c|c|}
\hline Treatments & \begin{tabular}{|c|}
$\begin{array}{c}\text { Cost of } \\
\text { Cultivation } \\
\left(\text { Rs. } \mathbf{h a}^{-1}\right)\end{array}$ \\
\end{tabular} & $\begin{array}{c}\text { Gross } \\
\text { returns } \\
\left(\text { Rs. } \text { ha }^{-1}\right) \\
\end{array}$ & $\begin{array}{l}\text { Net returns } \\
\left(\mathrm{Rs} . \mathbf{h a}^{-1}\right)\end{array}$ & B:C ratio \\
\hline T1: Absolute control & 59078 & $1,10,000$ & 50922 & 1.86 \\
\hline T2: RDF (75:75:100 kg/ha NPK) $\mathrm{K}$ as $\mathrm{KCl}+$ Sulphur (Equivalent to $\mathrm{K}_{2} \mathrm{SO}_{4}$ in T5) & 65359 & 193700 & 128342 & 2.96 \\
\hline T3: RDF (75:75:150 kg/ha NPK) K as $\mathrm{KCl}+$ Sulphur (Equivalent to $\mathrm{K}_{2} \mathrm{SO}_{4}$ in T6) & 66992 & 193700 & 126709 & 2.89 \\
\hline T4: RDF (75:75:175 kg/ha NPK) $\mathrm{K}$ as $\mathrm{KCl}+$ Sulphur (Equivalent to $\mathrm{K}_{2} \mathrm{SO}_{4}$ in T7) & 67809 & 230100 & 162292 & 3.39 \\
\hline T5: RDF (75:75:100 kg/ha NPK) $\mathrm{K}$ as $\mathrm{K}_{2} \mathrm{SO}_{4}$ & 72493 & 280500 & 208008 & 3.87 \\
\hline T6: RDF (75:75:150 kg/ha NPK) $\mathrm{K}$ as $\mathrm{K}_{2} \mathrm{SO}_{4}$ & 77693 & 283000 & 207308 & 3.67 \\
\hline T7: RDF (75:75:175 kg/ha NPK) K as $\mathrm{K}_{2} \mathrm{SO}_{4}$ & 80293 & 302800 & 216737 & 3.77 \\
\hline T8: RDF (75:75:100 kg/ha NPK) $\mathrm{K}$ as Bio $\mathrm{K}+$ Sulphur (Equivalent to $\mathrm{K}_{2} \mathrm{SO}_{4}$ in T5) & 64164 & 280900 & 221002 & 4.38 \\
\hline T9: RDF (75:75:150 kg/ha NPK) $\mathrm{K}$ as Bio $\mathrm{K}+$ Sulphur (Equivalent to $\mathrm{K}_{2} \mathrm{SO}_{4}$ in T6) & 65199 & 289200 & 245784 & 4.39 \\
\hline T10: RDF (75:75:175 kg/ha NPK) $\mathrm{K}$ as Bio $\mathrm{K}+$ Sulphur (Equivalent to $\mathrm{K}_{2} \mathrm{SO}_{4}$ in T7) & 65717 & 311500 & & 4.74 \\
\hline
\end{tabular}

Note: RDF: Rec. Dose of Fertilizer for potato (75:75:100 kg ha ${ }^{-1}$ NPK); FYM: Farm Yard Manure @ $25 \mathrm{t}^{-1}{ }^{-1}$, Sulphur from external source (T2 and T8 =17 kg, $\mathrm{T} 3$ and T9 $=25.5 \mathrm{~kg}$, T4 and T10=29.75 kg of Elemental Sulphur). 
Effect of different levels and sources of $K$ on total nutrient content $(N, P \& \mathbf{K})$ of potato

The total Nitrogen, phosphorus and potassium content in tuber differed significantly due to application of different rate and sources of $\mathrm{K}$. Significantly higher N,P and K content in tuber recorded with application 75:75:175 kg per hectare of NPK where K applied as Bio-K (Table 4) and was on par with application of $100 \mathrm{~kg}, 150 \mathrm{~kg}$ and $175 \mathrm{~kg}$ of $\mathrm{K}$ as SOP and bio-K at 100 and $150 \mathrm{~kg}$ along with recommended $\mathrm{N}$ and $\mathrm{P} \quad(75: 75 \mathrm{~kg} / \mathrm{ha})$. Significantly lower N, P and K content was recorded in absolute control and was on par with application of $\mathrm{K}$ as $\mathrm{KCl}$ at different rates $(100,150$ and $175 \mathrm{~kg} / \mathrm{ha})$

The increase in NPK content in potato tuber and haulm due to application of different rates and sources of potassium could be due to increased uptake by the plant and increased availability of nutrients, better root growth and increased physiological activity of roots to absorb nutrients. These results were in agreement with findings of Gupta and Saxena (1981).

Effect of different levels and sources of $K$ on Micronutrient content ( $\mathrm{Fe}, \mathrm{Mn}, \mathrm{Zn}, \mathrm{Cu}$ \& B) of potato (Table 5)

A significant difference was found with respect to DTPA extractable $\mathrm{Cu}, \mathrm{Zn}, \mathrm{Mn}, \mathrm{Fe}$ and $\mathrm{B}$ content in soil after harvest of potato crop due to different treatments imposed.

\section{DTPA extractable iron}

There is a significant differences were found between treatments with respect to DTPA extractable iron content of the soil after harvest of potato crop (Table 6). Significantly highest DTPA extractable iron content was found in $\mathrm{T} 1$ with absolute control $(11.23 \mathrm{mg}$ $\left.\mathrm{kg}^{-1}\right)$ followed by T2 $(75: 75: 100 \mathrm{~kg} / \mathrm{ha}$ NPK) $\mathrm{K}$ as $\mathrm{KCl}+$ Sulphur $\left(10.26 \mathrm{mg} \mathrm{kg}^{-1}\right)$ and T3 (75:75:150 kg/ha NPK) K as KCl + Sulphur (10.12 $\mathrm{mg} \mathrm{kg}^{-1}$ ) Among the bio-K and sulphate of potash treated plots significantly lowest DTPA extractable Fe content of soil was found in T10 (75:75:175 kg/ha NPK) K as Bio $\mathrm{K}+$ Sulphur $\left(9.10 \mathrm{mg} \mathrm{kg}^{-1}\right)$. 4.5.3.6.2 DTPA extractable manganese. There is a significant differences were found between treatments with respect to DTPA extractable manganese content of the soil after harvest of potato crop (Table 5). Significantly higher DTPA extractable manganese content was found in (T1) absolute control (14.84 mg kg-1) fallowed by T8 (13.56 mg kg-1) RDF (75:75:100 kg/ha NPK) K as Bio K + Sulphur and T2 $(75: 75: 100 \mathrm{~kg} / \mathrm{ha} \mathrm{NPK}) \mathrm{K}$ as $\mathrm{KCl}+$ Sulphur (13.15 mg kg$\left.{ }^{-1}\right)$. Among the bio-K treated plots lowest DTPA extractable manganese content of soil was found in T10 (11.55 $\left.\mathrm{mg} \mathrm{kg}^{-1}\right)$ RDF (75:75:175 kg/ha NPK) $\mathrm{K}$ as Bio $\mathrm{K}+$ Sulphur. 4.5.3.6.3 DTPA extractable zinc There is a significant differences were found between treatments with respect to DTPA extractable zinc content of the soil after harvest of potato crop. Significantly higher DTPA extractable zinc content was found in (T1) absolute control $\left(1.59 \mathrm{mg} \mathrm{kg}^{-1}\right)$. The treatments T2, T3, T5, T6 and $\mathrm{T} 7$ found on par with each other (1.53, $1.56, \quad 1.56, \quad 1.57$ and $1.55 \mathrm{mg} \mathrm{kg}^{-1}$ respectively). Lowest DTPA extractable zinc was found in treatment $\mathrm{T} 10\left(1.34 \mathrm{mg} \mathrm{kg}^{-1}\right)$ $(75: 75: 175 \mathrm{~kg} / \mathrm{ha}$ NPK) $\mathrm{K}$ as Bio $\mathrm{K}+$ Sulphur. 4.5.3.6.4 DTPA extractable copper There is a significant differences were found between treatments with respect to DTPA extractable copper content of the soil after harvest of potato crop. Increase in micronutrient content in potato due to application of Bio-K as $\mathrm{K}$ source was attributed to contribution of micronutrients from the $\mathrm{K}$ source as well as availability of native soil micronutrients enhanced uptake and accumulation in haulm and tuber. Similar 
results were also recorded by Trehan et al., (1994).

In potato growing area, due to intensive cultivation resulted in the occurrence of wide spread of potassium deficiencies. Bio- $\mathrm{K}$ is a rich source of potassium which is also supplies other plant essential nutrients (macro and micronutrients) and application of bio-K at the rate of $175 \% \mathrm{~K}$ with balance of $\mathrm{N}$ and $\mathrm{P}$ through fertilizers, resulted in highest yield of potato crop and this was highly significant compared with potassium chloride at 100 , $150,175 \% \mathrm{~K}$ with balance of $\mathrm{N}$ and $\mathrm{P}$ through fertilizers. The bio-k at rate of $175 \%$ $\mathrm{K}$ with balance of $\mathrm{N}$ and $\mathrm{P}$ through fertilizers, found more profitable compared to sulphate of potash at rate of $175 \% \mathrm{~K}$ with balance of $\mathrm{N}$ and $\mathrm{P}$ through fertilizers, with $\mathrm{B}$ : $\mathrm{C}$ ratio of 4.74 and 3.77 respectively.

\section{References}

Ahmed, A. A., Abd El-Baky, M.M.H., Faten S. Abd El-AAL and Zaki. M.F., 2009, Comparative studies on application of both mineral and biopotassium fertilizers on the growth, yield and quality of potato. Res. J. Agric.Biol. Sci., 5 (6): 1061-1069.

Anonymous, 2006, The Hindu, Survey of Indian Agriculture, 38-42.

Gomez, A. K. and Gomez, A. A., 1984, Statistical procedures for agricultural research. 2nd Ed. John Wiley and sons,
New York, USA, pp. 680.

Gupta, A. and Saxena, M. C., 1981, Effect of nitrogen and phosphorus fertilization on phosphorus and potassium content in different plant parts of potato. J. Indian Potato Assoc., 8 (2): 45-51.

Khurana, S. C., Bhatia, A. K., Bhutani, R. D. and Pandita, M. L., 1995, Evaluation of true potato seed families for seedling tuber production and ware crop. Haryana J. Hort. Sci., 24(3-4): 261-265.

Krishnappa, K. S. and Shivashankar, K. T., 1981, Effect of time and method of application of varying levels of nitrogen on yield and yield attributes of potato. Madras Agric. J., 68 (3): 183-188.

Sharma, R.C., I. S. Grewal and KC. Sud. 1976. Relative suitability of different phosphatic sources for potato on brown hill soils of Shimla. Journal of Indian Society of Soil Science 24: 95-97.

Trehan, S.P. and J,S. Grewal. 1994a. Judicious use of micronutrients for potato. In: Potato- Present and Future (G.S. Shekhawat et al., Eds.), Indian Potato Association, CPRI, Shimla pp. 151.

Zameer Khan, M. Ehsan Akhtar1, M. Naeem Safdar, M. Masud Mahmood, M. Sagheer Ahmad and Ahmed N., 2010, Effect of source and level of potash on yield and quality of potato tubers. Pak. J. Bot., 42 (5): 3137-3145.

\section{How to cite this article:}

Mohan, G.L., S. Channakeshava, N.B. Prakash, S.T. Bhairappanavar and Tambat, B. 2017. Effect of Different Rates and Sources of Potassium on Growth, Yield and Quality of Potato (Solanum tuberosum L.). Int.J.Curr.Microbiol.App.Sci. 6(11): 443-452. doi: https://doi.org/10.20546/ijcmas.2017.611.052 